\title{
POSSIBILITIES OF PARTICIPATION OF MILD MENTALLY RETARDED ADULTS IN THE LABOR MARKED RELATIONSHIPS
}

\author{
Pieaugušo ar vidēji smagiem garīgās attīstības traucējumiem \\ iesaistǐšanās iespējas darba tirgus attiecībās
}

\author{
Adolfas Juodraitis, Liuda Radzevičienė \\ Šiauliai Univeristy, Lithuania \\ E-mail: sppkatedra@cr.su.lt
}

\begin{abstract}
Problem of long life learning talking about educational and integration processes of mild mentally retarded adults in present economical situation face with new and unsolved problems. Changing labor market appreciates creativity and innovations and employers look for employees who can easily deal with difficult situations. It concerns certain mild mentally retarded adults, who have great problems in finding and then keeping their post. The aim of this research is to identify and define main characteristics and possibilities of long life education of mild mentally retarded adults and role of educator in these long term process.
\end{abstract}

Keywords: education of mild mentally retarded adults, educator, employment.

The problem of mild mentally retarded adults, who belong to the group of socially disadvantaged people, becomes more and more universal and hard to be solved. Such persons require special interest and help if they are to be successful in discovering and succeeding in their in education. Concept of "long life learning" mostly directed for non-disabled adults, and it's a problem when we are talking about adults which requires everyday care and additional resources of educational activities.

Today's reality, full of changes and uncertainty, provides us even more challenges. The labor market appreciates creativity and innovations. This requires developing certain special abilities such as making decisions, creative thinking, and dealing with stress and openness with a risk. Because of this, the risk of social disadvantage rises. Mild mentally retarded adults being in the situation of social disadvantaged cannot deal in an adequate way with their duties (Baranauskiené, 2002, 2007; Baranauskienė, Juodraitis, 2008; Kučinskas, Kučinskienė, 2000). This causes further social problems and threats e.g. unemployment, criminality, frustrations, psychological diseases etc. So, we face with situation of strong need to educate them in a direction of creativity, innovation, and a spirit of enterprise. This concerns mild mental retarded adults, who have great problems in finding and then keeping their post. The situation of social disadvantage adults and their possibility to take part in long life learning activities and participation in labor market actively depends on educators, societal attitudes to the work abilities of mentally disabled adults.

Participant of mentally retarded in the labor market is important integration activity and at the same time it is a form of social rehabilitation. Educational aspect of work activity of mentally retarded can be assessed as increasing processes of 
Proceedings of the International Scientifical Conference. Volume II: Social and Special pedagogy; Health and Sport; Overviews. self-confidence, as well (Epstain, Polloway, Patton, Foley 1989; Soderback I. (2010). Successful education and integration to the labor market and maintenance of job skills of mild mentally retarded in many cases depends on the societal attitudes, type of the offered work, and individual characteristics of mild mentally retarded person. These factors are significant determinants of person's efficiency. The job skills of mentally retarded are stable and without significant educational efforts they are hardly to be changed (Hallagan, Kauffman, 1991). Sometimes, work skills are going to get poor and it creates a lot of problems for employers, colleagues, depends and for mentally disabled person, as well. According to P.Jucevičiene (1997) for the forming of positive attitudes of society to mild mentally retarded and for successful integration to labor market there are important three factors: 1.Level of disability, 2.Social environment, and 3.Type of work activity. This complex of mentioned factors must be developed in the socioeducational activity, in which experience and professional competences of social pedagogue is significant. Relationship is a dimension that might stimulate openness of mild mentally retarded and creating of "friendly environment". Communication skills are a problematic sphere of interaction behavior for mentally retarded people. Job is always connected in close relationships with other people and that's why particularities of interaction determinate societal attitudes on mentally disabled (Shahida, 2004; Radzeviciene, Juodraitis, Kazlauskas, 2005) Workload and particular conditions of work environment forms some specific societal attitudes, also. Because of some other type of attention, reaction, endurance, weariness, tend to conflicts with environment, the quality of work may suffer. These specific characteristics indicate that some other kind of ergonomic requirements (workplace and whole environment) must be shape. Social environment is one of the most important factors for the societal acceptance and education of mild mentally retarded adults. The concept of social environment is rather multi-meaningful and in the aspect of work ability it is described as the interaction of institution, family of the disabled and community.

Object of the research: Education possibilities of mild mentally retarded adults in the situation of employment.

Aim of the research: To reveal possibility of long term education of mild mentally retarded adults to get into the labor market.

\section{Goals of the research:}

1. To realize theoretical backgrounds concerning education into employment of mild mentally retarded adults.

2. To reveal possibility of educational activities and personal perception on the possibility to get into the labor relationships.

\section{Method of the research:}

This study presents a part of the research data: questions that might help to reveal the educational particularities and personal attitudes on the disability in the situation of getting in the labor relationships. 


\section{Results of the Research and Discussion}

41 mild mentally retarded adults from 18 to 36 year of age visitors of Day care Center of Siauliai city took place in this research. Part of them (18 persons) was in short term labor relationships and others were unemployed. Most part of them is people from 24 to 29 year of age (Fig.1). In ordinary life style, this age group is active, creative and self-confident enough solving social questions and dealing with different types of social situations in their life. They are responsible not only of their self's, but for their nearest environment, as well.

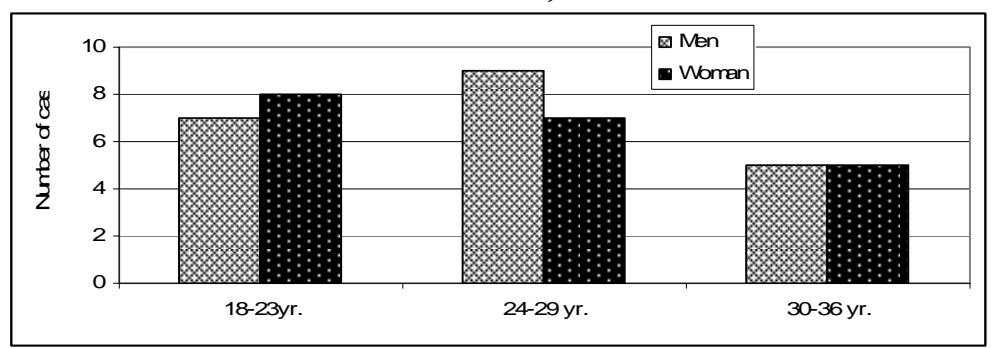

Figure 1. Participants according to the age and gender

It was revealed that Day Centers are attended by young adults most of all. After some educational experience they try to go somewhere else to keep contacts with others, to spent free time. Parents prefer to let their disabled children into any organized institution of education or institution of social services. But later number of mild mentally retarded adults attending Day center began to decrease. There are a lot of problems and the separate study could be done, analyzing why older mentally retarded adults are not involved in the activities that were acceptable for them.

There were no young adults $(18-23$ years of age) who have a work place. They are visitors of day center, but financially they depend on their family members. As a rule, mentally retarded has some group of invalidity that depends on their mental and somatic health. Parents have no experience and confidence to let their children to work. They have no experience and have no knowledge. It means that educational activities are needed for parents, as well. Most of the visitors are young people and they are potential participants of labor market activities. Work abilities and possibilities of mentally disabled adults in the situation of market economics are still quite problematic link in the industrial and educational reality and these problems connected with this age group directly.

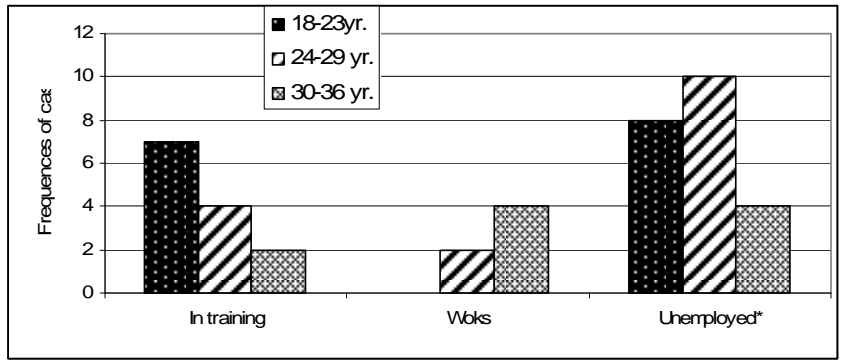

* - Level of significance $p=0,03$

Figure 2. Occupation of the participants 
Most of mentally retarded adults are unemployed, because the main group of respondents has insufficient work abilities. It means that their dependence on the environment, social, education services is rather high and they can act with help of other person or they need some special environmental equipment for their excitation. From the point of view of work perspective they make a large possible group that could join to market relationship. But the significant attempts must be put in order to motivate them for work activity. It was set up that only $1 / 3$ of all participants were in service training.

Social situation of mild mentally retarded people reflects their monthly incomes. Monthly incomes can be as salary, social relief, and pension, incomes shared with other members of person's family. Pension of disabled who belong to the first invalidity group is largest one in comparison with others. But as we realized people who have lowest monthly incomes in many cases belong to the second invalidity group. People who have monthly incomes 228 EUR (it is minimal monthly salary, http://www.socmin.lt/index.php?1452431613), can be assessed as people living on the edge of poverty. According our research the main part of mild mentally retarded persons presents the poorest part of our society, that's why education system must face and be enlarged.

We set up that a little part of respondents is in the work relationships and most of mild mentally retarded adults are out of job (Fig.2). In spite of the fact, that in some cases mild mentally retarded persons could have a job, monthly incomes are not significant larger then in other analyzed cases. It means that mild mentally retarded adults are paid worse than other workers. It happens due to their low qualification, insufficient motivation and due to personal features, that common to mentally retarded persons.

Some of respondents were unemployed and some of them were in training. We found out that there were some mild mentally retarded persons who were in training activities during the research period (Fig.2). It means, that they want and able to join educational process according their individual needs and possibilities. We see also that there is no significant links between training and monthly incomes. Sometimes parents or organizations pay for persons' studies, so it means that some of them are motivated to integrate to socio-cultural and economical life.

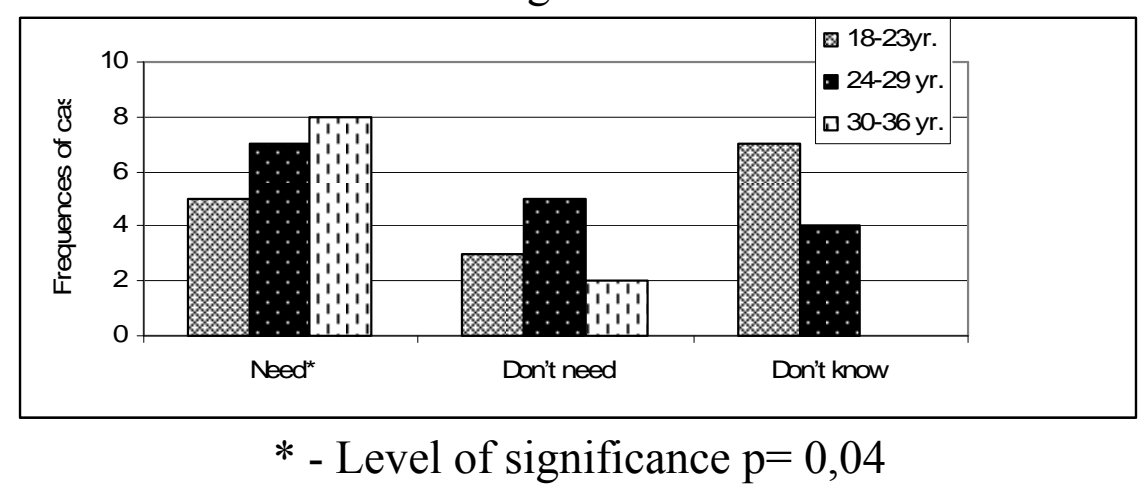

Figure 3. Need for Education Support 
It was interesting to assess how mentally retarded adults understand their situation in long life learning aspect. Most of them said that they need more education activities, and we reveal that as adult is older, the education is need much more. Young adults are not able to assess their situation, because most of them live with parents, and older ones, has an experience of independent life. It was a large group of adults, who don't know do they want any additional education. So, we assess them as a most potential group for learning activities. Talking about long term education processes it must be oriented into all groups of mild mentally retarded adults. We can do premise, that much more attention must be paid to young and middle age mild mentally retarded persons in activating them for labor activities. According occupation the main group of respondents are unemployed, so it reflects the opinion of society on possibility to get into the labor relationship.

Theoretically society is welcoming attempts of mentally disabled to participate in the labor marked relationships (Radzeviciene, Juodraitis, Kazlauskas, 2005) and labor marked must be more flexible for the job needs of mentally disabled, because society is open to meet them (some of the respondents participate in job activity). Research results enable educators for creation of effective solutions and methods, which would be helpful in the development of innovative attitudes among disadvantaged people. Content of these methods might stress promotion of knowledge concerning innovation, creativity and a spirit of enterprise, as well as with a creation of social movement of an idea of a "subjectivity education".

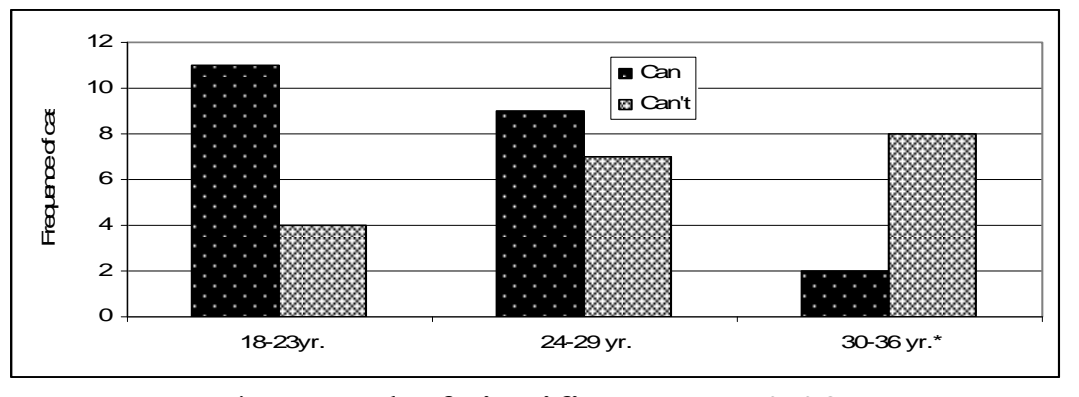

* - Level of significance $p=0,02$

Figure 4. Re - skilling in the situation of disability

In the situation of mental disability problem of re-skilling became evident. It happens because mild mentally retarded adults during their education in special schools obtain some narrow specialization and in the conditions of changing economy it is complicated to find work for them. Re-skilling is one of the opportunities to involve mild mentally retarded adults in labor relationship. The research reveals that the largest part of respondents can't obtain new work skills. It concerns people at the age of $24-29$ most of all. Again we see the situation when young mild mentally retarded adults, because of their disability are unable to increase their work skills. Situation became worse talking about re-skill opportunities for the adults, who are $30-36$ years of age $(p=0,02)$, because social 
Proceedings of the International Scientifical Conference. Volume II: Social and Special pedagogy; Health and Sport; Overviews. welfare system and system of special education are oriented to young people most of all.

According to the results of the research we can do some conclusions, which reflect common situation of education needs and role of teachers, working with mild mentally retarded adults in the situation of market relationships. It is not a duty of social worker to create and work with re-skilling programs, but in our situation social worker is needed to know where and how to help adult to get adequate education. So, crucial role in long term learning plays teacher, who orientates and prepares mild mentally retarded adult for his active participant in societal life.

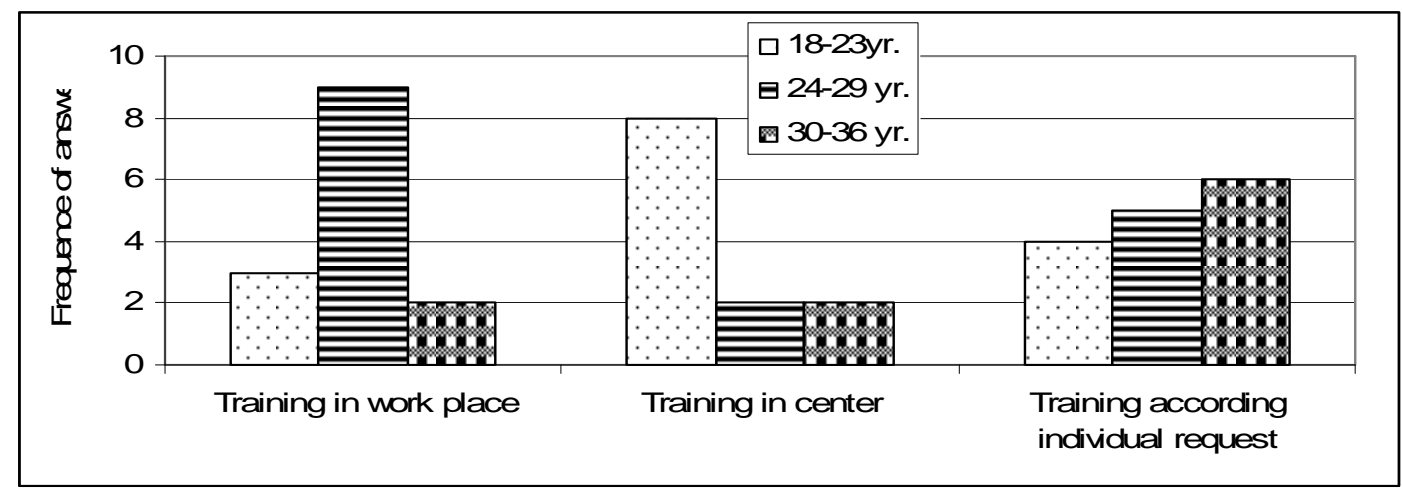

Figure 5. Place of training of mild mentally retarded persons

There are some places of educational activities that mild mentally retarded adults prefer (Fig.5). The youngest ones prefer to learn in centers, it means they don't want to change known routine, they prefer to be with the same people and in known environment. They are not really mature for independent life and it reflects on a lack of responsibility for their own decisions. As adults become older they accept possibility to join real work place, and they want to learn in working place. But older group (30 - 36 years of age) prefers training according individual needs. It means that adults understand that at this age it's normal to know how to work and on the other hand, this fact reflects societal attitudes to long - term learning. For many of people it's unaccountable to learn the same things all the time. So, education spreads in one more sphere - education of society, institutions, in which mild mentally retarded are going to work. As we realized that sometimes persons with mild mental retardation are not adequate in choosing one or other type of education. Analyzing questionnaire we let some free space to indicate their wishes. So, 23 from 41 indicate university degree, others prefer to continue studies or obtain qualification in foreign countries. Such decisions are based on practical experience, because a lot of people from their nearest environment successfully transmigrated to Western countries. We do not think that idea about international changes of mild mentally retarded students is impossible. Integration processes in any modern system of education can't be limited by located space and it's possible that future cosmopolitan mode of life will suggest new concepts of integration processes. 


\section{Conclusions}

1. The situation of social disadvantage adults and their possibility to take part in labor market actively depends on work abilities of mentally disabled adults and their level of education.

We face with situation of strong need to educate mild mentally retarded adults in a direction of creativity, innovation, and a spirit of enterprise, because for all of them most problematic thing is to find and keep their post..

The situation of social disadvantage adults and their possibility to take part in long life learning activities and participation in labor market actively depends on educators, societal attitudes to the work abilities of mentally disabled adults.

2. According to the research data the main group of respondents has certain groups of invalidity. From the point of view of work perspective they make a largest possible group that could join to market relationship. So the significant attempts must be put in order to motivate them for work activity.

Most of mentally retarded adults are unemployed, because the main group of respondents has some group of invalidity. It means that their independence is rather high and they can do and act with a little help of other person or they need some special environmental equipment for their excitation.

3. According our research the main part of mild mentally retarded persons presents the poorest part of our society, that's why education system must face and be enlarged.

4. Mild mentally retarded adults want and are able to join educational process according to their individual needs and possibilities. We found out that there is no significant links between participation in training processes and monthly incomes.

5. According occupation the main group of respondents is unemployed. Labor marked must be more flexible for the job needs that mentally disabled have. Research results enable educators for creation of effective solutions and methods, which would be helpful in the development of innovative attitudes among disadvantaged people.

Talking about long term education processes it must be oriented into all groups of mild mentally retarded adults. We can do premise, that much more attention must be paid to young and middle age mild mentally retarded persons in activating them for labor performance. It enables educators for creation of effective solutions and methods, which would be helpful in the development of innovative attitudes among disadvantaged people. Content of these methods might stress promotion of knowledge concerning innovation, creativity and a spirit of enterprise, as well as with a creation of social movement of an idea of a "subjectivity education".

6. Re-skill is one of the opportunities to involve mild mentally retarded adults in long term learning process. The research reveals that the largest part of respondents can't obtain new work skills (people at the age of $24-29 ; \mathrm{p}=0,02$ ), 
Proceedings of the International Scientifical Conference.

Volume II: Social and Special pedagogy; Health and Sport; Overviews.

because of disability they are unable to increase or change their specialization skills.

7. Education process among mild mentally retarded adults is still unsolved problem; because social welfare system and system of (special) education are oriented to young people most of all.

\section{Bibliography}

1. Baranauskienè, I.(2002). Neigaliujų profesinis rengimas: kaip ekspertai vertina švietimo, ekonominès ir socialinès politikos sąveiką? //Specialusis ugdymas. Mokslo darbai.1(6), p.7284.

2. Baranauskienè I., Juodraitis A. (2008) Neigaliuju profesinè reabilitacija: sékmés prielaidos. Monografija. Šiaulių universiteto leidykla. Šiauliai, UDK 331.5-056 Ba399. ISBN 978-9986-38-909-5. p. 430. 27 leidybiniai apskaitos lankai.

3. Epstain, M., Polloway, E., Patton, J., Foley, R.(1989). Mild retardation: Student characteristics and services. Education and Training in Mental Retardation., 24 (1).

4. Hallagan, D., Kauffman, J.(1991).Exeptional Children. Introduction to special education (5th ed.). Massachusetts. Allyn and Bacon.

5. Hopkins, H.L.,Smith, H.D.(1988). Willard and Spackman's Occupational Therapy. (7th ed.). Lippincott Company, Philadelphia.

6. Jucevičienè, P.(1997).Ugdymo mokslo raida: nuo pedagogikos iki šiuolaikinès edukologijos. Kaunas.

7. Kučinskas, V., Kučinskienè, R. (2000). Socialinis darbas švietimo sistemoje. Teoriniai aspektai. Klaipèda. Klaipèdos universitetas.

8. Radzevičienè, L., Juodraitis, A., Kazlauskas, A. (2005). Visuomenès požiūris ị psichikos negalę turinčių suaugusiųjų darbinius gebejjimus. Specialusis ugdymas. Nr.1 (), $p$.

9. Shahida S. (2004). The status of vocational training programs for the disabled persons in Pakistan. Summary of Dissertation thesis. University of Karachi Department of Special Education.

10. Soderback I. (Ed.). (2010). International handbook of occupational therapy interventions. 1ed. Amazon Digital Services.

11. Anual Report of Ministry of Social Security and Labor http://www.socmin.lt/index.php?1452431613 (access to internet 10.02.2012)

\begin{tabular}{|cl|}
\hline Adolfas Juodraitis & $\begin{array}{l}\text { Šiauliai Univeristy, } \\
\\
\\
\text { Faculty of Social Welfare and Disabilities Studies } \\
\text { E-mail: sppkatedra@cr.su.lt }\end{array}$ \\
\hline Liuda Radzevičienė & Šiauliai Univeristy, \\
& Faculty of Social Welfare and Disabilities Studies \\
& E-mail: sppkatedra@cr.su.lt \\
\hline
\end{tabular}

